\title{
QUALITY ANALYSIS OF SINGLE TREE OBJECT WITH OBIA AND VEGETATION INDEX FROM LAPAN SURVEILLANCE AIRCRAFT MULTISPECTRAL DATA IN URBAN AREA
}

\author{
N. M. Sari ${ }^{\text {a }}$ D. Kushardono ${ }^{\text {a }}$ \\ ${ }^{a}$ Remote Sensing Application Center, Indonesian National Institute of Aeronautics and Space (LAPAN), Indonesia
}

\section{Article Info:}

Received: 17 June 2016

in revised form: 19 July 2016

Accepted: 19 August 2016

Available Online: 31 October 2016

\section{Keywords:}

Aerial remote sensing, LSA, OBIA NDVI, vegetation urban

\section{Corresponding Author:}

Nurwita Mustika Sari

Remote Sensing Application Center,

Indonesian National Institute of

Aeronautics and Space (LAPAN),

Jakarta, Indonesia

Email: nurwita_sutaat@yahoo.com

\begin{abstract}
High-resolution remote sensing data as the acquisition result of LAPAN Surveillance Aircraft (LSA) has the potential to analyze urban areas. The purpose of this study was to develop a method of LSA multispectral data utilization with an analysis of the single tree object in urban areas with OBIA and vegetation index. The method proposed in this study is a hierarchical classification to obtain the specific tree object that will be used further to analyze the quality of vegetation. In particular, analysis of the vegetation quality on the tree object was carried out by calculating the value of vegetation index NDVI. As a result, the overall accuracy of the hierarchical classification of objects in urban areas reached $88 \%$. In conclusion, the analysis of the quality of vegetation NDVI has been able to perceive the condition of trees in the urban area.
\end{abstract}

Copyright (C) 2016 GJGP-UNDIP This open access article is distributed under a Creative Commons Attribution (CC-BY-NC-SA) 4.0 International license.

How to cite (APA 6th Style):

Sari, N. M., and Kushardono, D. (2016). Quality analysis of single tree object with OBIA and vegetation index from LAPAN surveillance aircraft multispectral data in urban area. Geoplanning: Journal of Geomatics and Planning, 3(2), 93-106. doi:10.14710/geoplanning.3.2.93-106

\section{INTRODUCTION}

The existence of vegetation in urban areas plays an important role in improving urban air quality, where the role of such vegetation is influenced by good penetration to precipitate pollutant particles in the air (Janhäll, 2015). Although the effect is small, the trees in the urban area have an effect on the content of $\mathrm{NO}_{2}$ around the route traffic (Grundström \& Pleijel, 2014). By modeling the heat and wind data, it is known that the vegetation in urban areas contributes to lowering the temperature of the surrounding air and become the patron of the effects of wind and sunlight, and also increase the moisture (Boukhabl \& Alkam, 2012). On the other hand, some types of the urban tree have a role in the microclimate engineering effort (Takács et al., 2016). The role of urban vegetation can be observed in the modification of the microclimate when vegetation area is known to have a temperature lower than the built up area (Buyadi, Mohd, \& Misni, 2015). Even in other ecological functions, vegetation in a city park can create new habitats for bird communities in the middle of extreme land changes due to human activities (Kerr \& Dobrowski, 2013).

The utilization of remote sensing data for detecting urban vegetation was carried out by $\mathrm{Zhang}, \mathrm{Wu}$, and Chen (2010). The authors conducted a study of urban vegetation from Landsat TM Beijing using vegetation index and brightness temperature derived from these data. Zain et al. (2015) performed detection of urban green space in Jakarta, Bogor, Depok and Tangerang using Landsat 7 ETM+. However, Landsat imagery analysis carries constraints including difficulty during cloud coverage in the coverage area of agricultural land as well as acquiring ambiguity during the dry season (Saripin, 2003). Other problems arise at the utilization of imagery with middle or low resolution. Pixel mixture problem can indicate incongruity of observation scale used for the process with the diversity of landscapes in the study area. It can be exemplified by the difference between Landsat and IKONOS where Landsat shows the homogeneity of the area, compared to appeared variations at IKONOS (Blaschke et al., 2000). 
Utilization of vegetation indices derived from remote sensing has the potential to be applied widely including for water resources management (Kumar, 2015), and land cover change detection (Aburas et al., 2015). Vegetation indices derived from the remote sensing data (NDVI) were similarly used to see vegetation changes on the lagoon restoration (Kim et al., 2015), on various types of land cover (Gandhi et al., 2015), and on multi-temporal monitoring of plantation phenology (Jayawardhana \& Chathurange, 2016). Also, the utilization of data with high-resolution GeoEye-1 can be applied to analyze the condition of vegetation with NDVI (Rajendran, Al-Sayigh, \& Al-Awadhi, 2016). Vegetation indices such as NDVI, EVI2, and NDSBVI were used to discover annual cropping pattern in one of the districts of India (Mondal et al., 2014).

In some studies, detailed-scale mapping was obtained using high-resolution satellite imagery, such as the production of large-scale maps of 1: 5000 for Tripoli area, Libya using QuickBird imagery. This image is a good data source for large-scale maps (Said, Shandoul, \& Yekhlef, 2013). In archaeology, a very highresolution satellite imagery QuickBird-2 was furthermore implemented to detect pent building area and building extraction from QuickBird and WorldView-2 (Belgiu \& Drăgut, 2014; Kaimaris, Patias, \& Tsakiri, 2012). High-resolution IKONOS data has been used to perform Torreya endemic vegetation mapping in South China and gained $81.7 \%$ accuracy for the object-based method. It shows that certain vegetation mapping can be carried out using the high-resolution remote sensing data such as IKONOS (Wang, Wang, \& Zhou, 2011). Another VHR satellite data Pleiades-1A has been used by Zylshal et al. (2016) to extract the urban green space in Jakarta, Indonesia.

The development of aerial remote sensing and aerial vehicles to conduct acquisition grows very rapidly following the increase of high-resolution remote sensing data need in Indonesia. One of the aerial vehicles, namely drones or UAVs, is now applied in various fields including remote sensing mission (Kushardono, 2014). A manned aerial vehicle named LAPAN Surveillance Aircraft (LSA), is another type developed by LAPAN (Indonesian National Institute of Aeronautics and Space). LSA has great potential to perform remote sensing mission and provide detailed-scale data (Kushardono et al., 2014). With the resolution of up to 58 $\mathrm{cm}$, objects in the image will look exactly clear and requires an object-based method for the separation of objects contained in the image. Implementing this method, Sari and Kushardono (2014) carried out a classification of land cover with textural features Haralick. OBIA data processing was more effective for the imagery containing clearly visible objects, as shown Pedersen (2016) in glacio-volcanic landform classification (glaciovolcano) with geomorphometry point of view. Blaschke et al. (2014) revealed how GEOBIA had grown rapidly, becoming a solution of limited pixel-based analysis and in the end concluded GEOBIA as a new paradigm.

LAPAN Surveillance Aircraft data utilization for vegetation study carried them to observe the quality of vegetation at urban green open space (Sari \& Kushardono, 2015). Moreover, the initial processing of multispectral data LAPAN has been carried out by Chulafak, Annas, and Kushardono (2015), especially for agricultural monitoring. This study aimed to assess the urban area more importantly compared to rural areas. Urban areas have more complex and diverse land use problems including ecological, social and environmental aspects (Du, 2016). That is why the study of the vegetation in the urban area has become an important case. If succeeded, the proposed method is expected to be applied to a less complex rural area. On the other hand, it is expected to not only be used in generating aerial remote sensing data but correspondingly in acquiring better and standard satellite data with very high spatial resolution.

This research is the development of previous research related to urban green open space extracted from LSA data. The purpose of this study is to develop a method of data LSA multispectral data utilization with the analysis of single tree object in the urban area with OBIA and vegetation index to study the quality of urban vegetation.

\section{DATA AND METHODS}

\subsection{Data}

In this study, the used imagery data was a multispectral image data acquired by the Aeronautic Technology Center LAPAN at September $18^{\text {th }}-19^{\text {th }} 2014$. The coverage area was mostly urban area of Indramayu, West Java. Data were previously collected and processed to be a mosaic, followed by an orthocorrection by Remote Sensing Application Center LAPAN (Kushardono et al., 2014). The data was acquired 
by the multispectral camera Tetracam-ADC with 3 bands (Red, Green, and NIR) flying at an altitude of 2000 $\mathrm{m}$ and has a spatial resolution of $58 \mathrm{~cm}$ (Figure 1).

Figure 1. Mosaic result data that is used as the main data of the study (Kushardono et al., 2014)

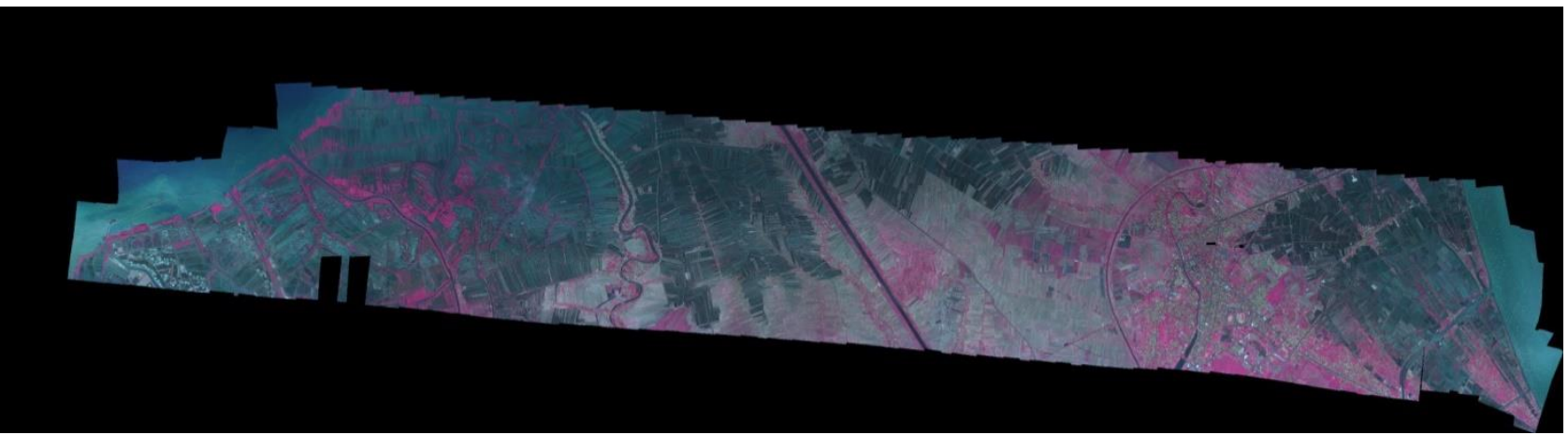

\subsection{Methods}

Stages of data processing performed in this study initiated with the cropping process of the mosaic image data to area which is the focus of the study (Figure 2). Then, in contrast to previous study by Sari and Kushardono (2015), this study proposed a hierarchical classification of objects with the segmentation process (OBIA), followed by the selection of specific tree object for further analysis of the vegetation quality. Thus at single tree objects, the vegetation quality analysis was conducted by calculating the vegetation index or NDVI value resulting the quality of vegetation namely tree in particular.

Figure 2. Data processing stages of LSA photos for urban single object vegetation quality analysis (Authors, 2016)

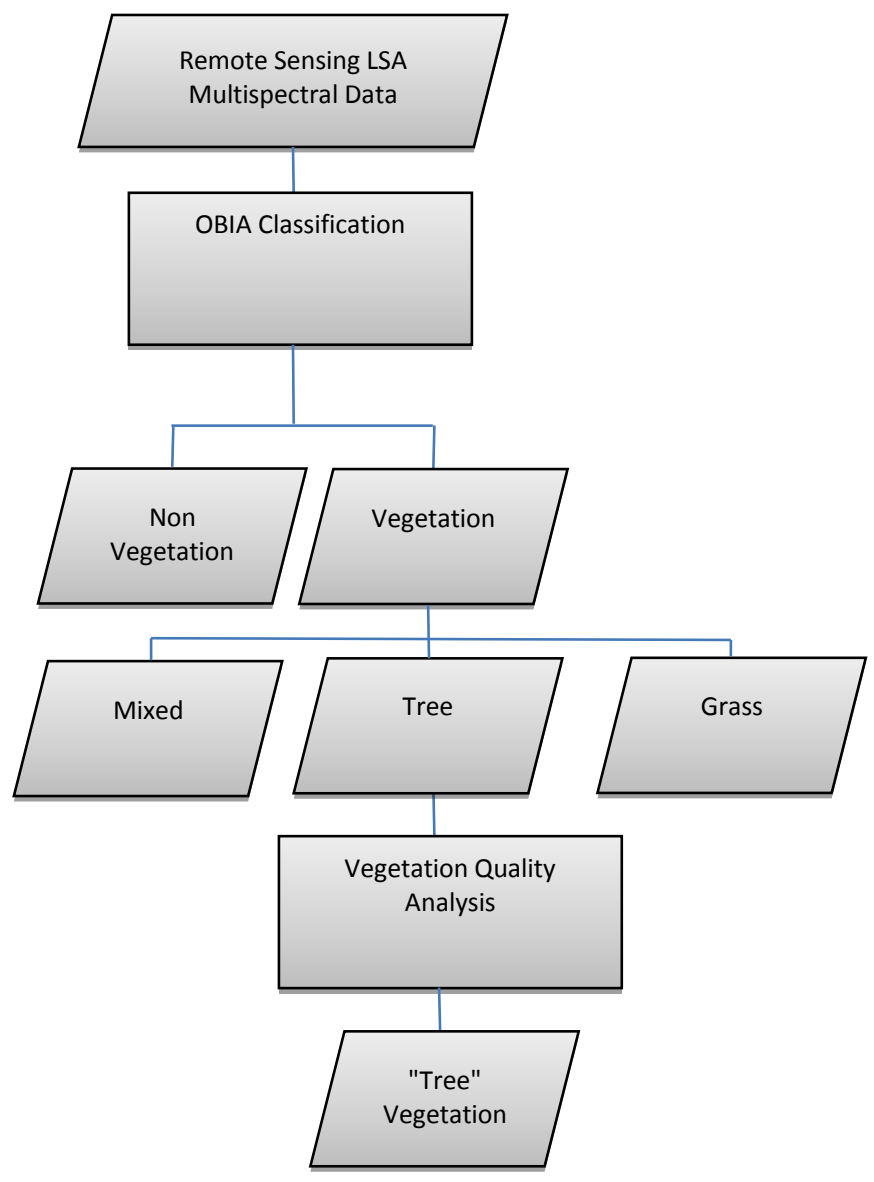


a. Cropping data LSA

Cropping the LSA multispectral data for Indramayu area has been done for urban area, as shown in Figure 3 below.

Figure 3. Cropping result of LSA multispectral remote sensing data at Indramayu, West Java (Kushardono et al., 2014)

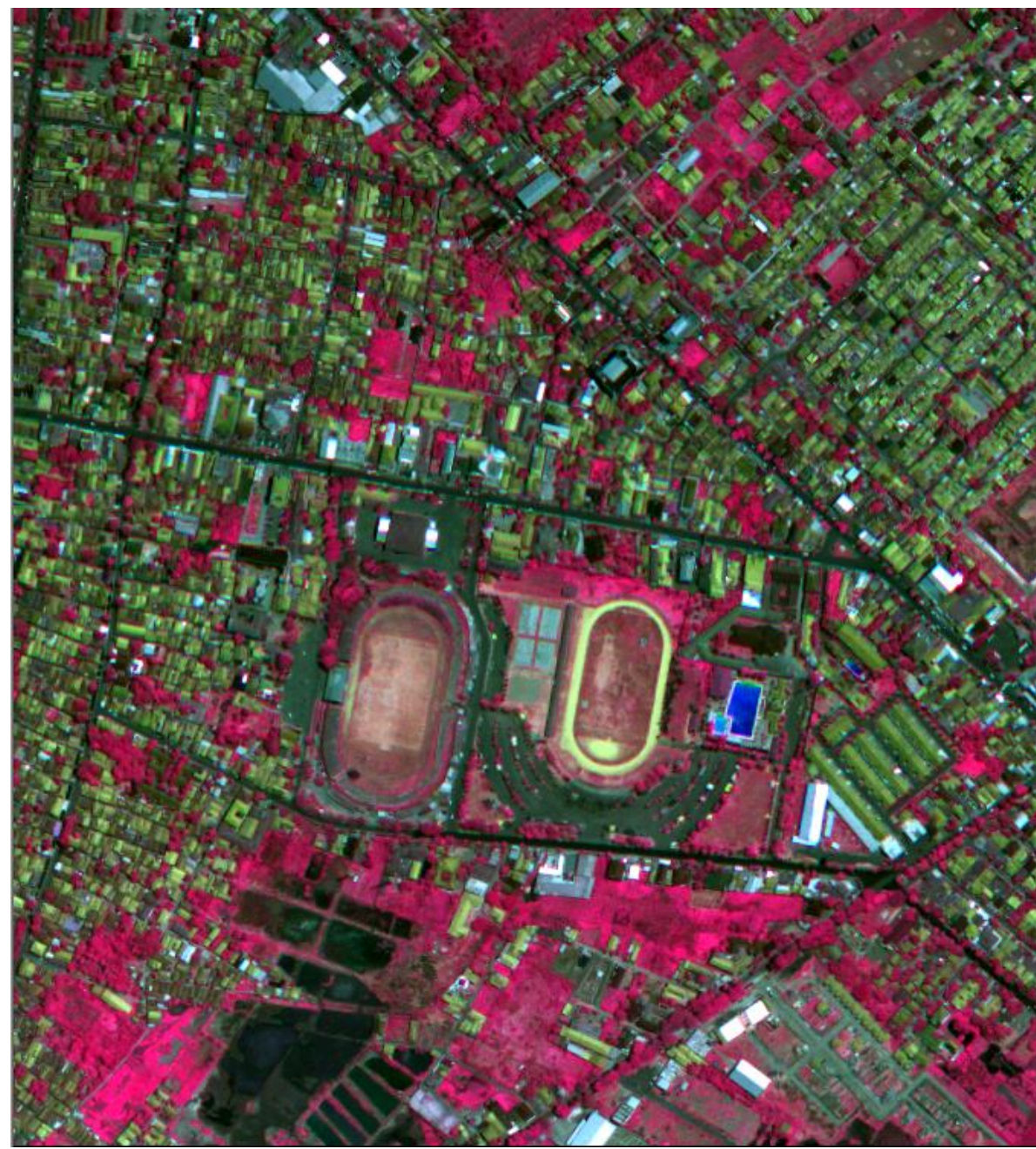

\section{b. Image segmentation and classification}

OBIA (Object Based Image Analysis) process includes segmentation of the object in the image and object-based classification. Segmentation was carried out by multiresolution segmentation algorithm using the most appropriate scale parameter to obtain the best segmentation results. Baatz and Schäpe (2000) revealed the criteria for the evaluation of segmentation results would be obtained quantitatively and qualitatively. Quantitatively, the heterogeneity of each pixels should be lowered, while qualitatively the most important thing is the result of segmentation. It should look visually decent because, in principle, segmentation is a form of automation of image analysis which replaces visual digitizing. Mathematically, Baatz and Schäpe wrote relationship between concordance rate $(\mathrm{h})$ with feature-dimensional space (d) of two adjacent image objects as followed:

$$
h=\sqrt{\sum_{d}\left(f_{1 d}-f_{2 d}\right)^{2}}
$$


In multiresolution segmentation algorithm, the most effective scale to separate the object must be found. Scale is a user-defined limit on heterogeneity tolerated on the result of the segmented object. At the larger scale, the more objects were incorporated; the greater result of segmented object was recovered and vice versa (Karakiş, Marangoz, \& Büyüksalih, 2006).

Segmentation was conducted to separate the non-vegetation object from the whole object. The initial classification was done by separating the vegetation and non-vegetation using brightness, compactness, density feature and spectral mean value of each band. This work is the development of previous study conducted without using spectral band value (Sari \& Kushardono, 2014). Training data for initial classification have been chosen in the vegetation and non-vegetation, for every different appearance within a class.

Figure 4. Training data for classification 1 (Sari \& Kushardono, 2014)

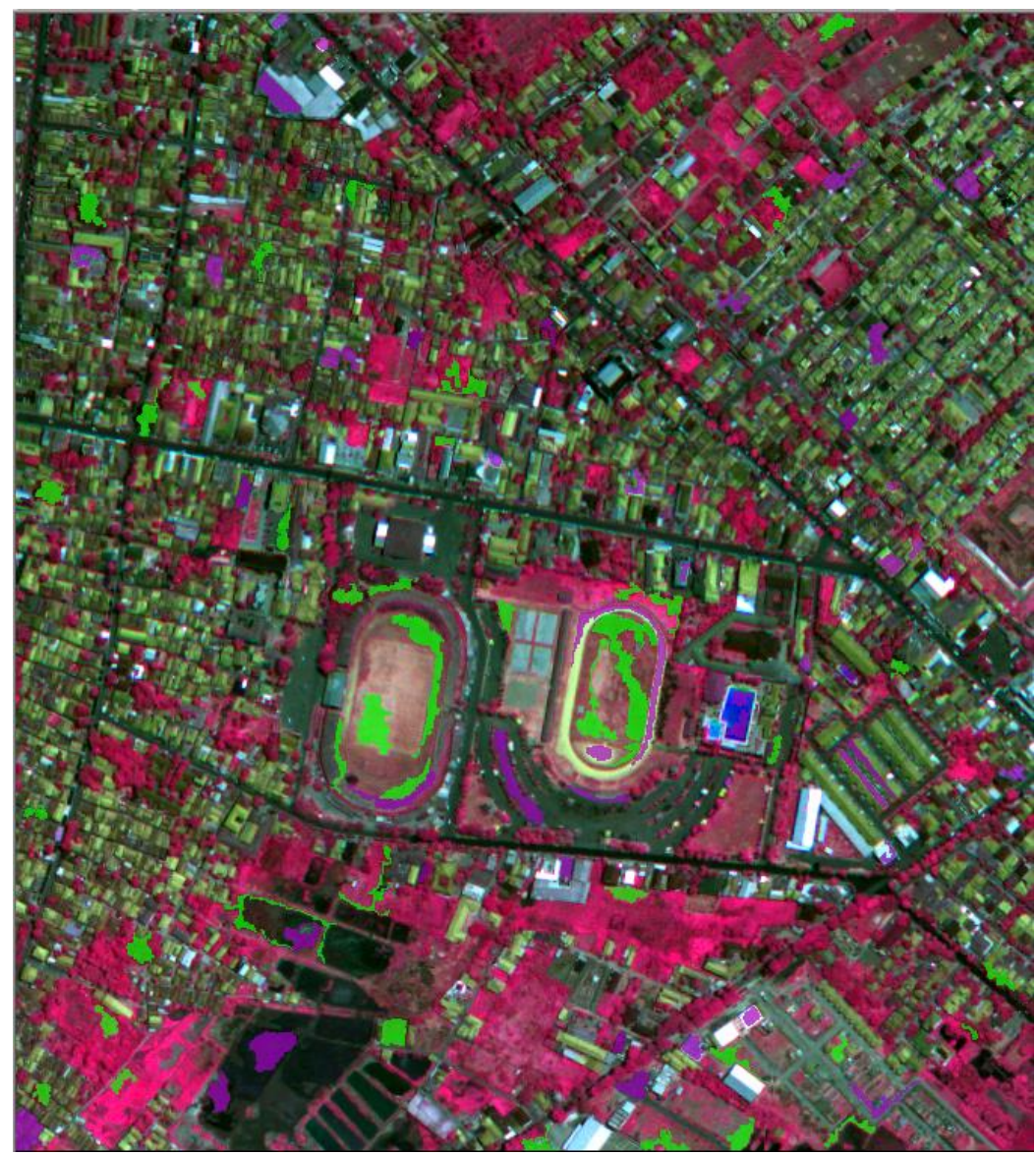

Segmentation and second classification were performed only on vegetation classes, where such vegetation will be classified into a tree and non-tree (grass, mixed cropping) using the input of the same features (brightness, compactness, density and spectral mean value) of each band.

\section{c. Analysis of the quality of vegetation in the tree using NDVI}

Analysis of the quality of vegetation in a specific area of trees in the study is an extension of previous research conducted on vegetation in general in urban green open space (Sari \& Kushardono, 2015). In this study, the analysis was conducted with the detailing of vegetation object segmentation (OBIA) to achieve the object of vegetation up to single vegetation. The quality of this vegetation will be analyzed from the NDVI (Normalized Difference Vegetation Index) since this value has been proven to have a high correlation with vegetation parameters. This index has a strong sensitivity of the existence of vegetation through a process of active photosynthesis (Tucker, 1979). 


$$
\mathrm{NDVI}=\frac{N I R-R E D}{N I R+R E D}
$$

\section{RESULTS AND DISCUSSION}

The separation of the object (segmentation) conducted in the study area practiced trial and error to get the best result obtained at a scale of 30 , whereby the separation of the object were made up to a single object vegetation (see Figure 5).

Figure 5. Segmentation results LSA at scale of 30 (Analysis, 2015)

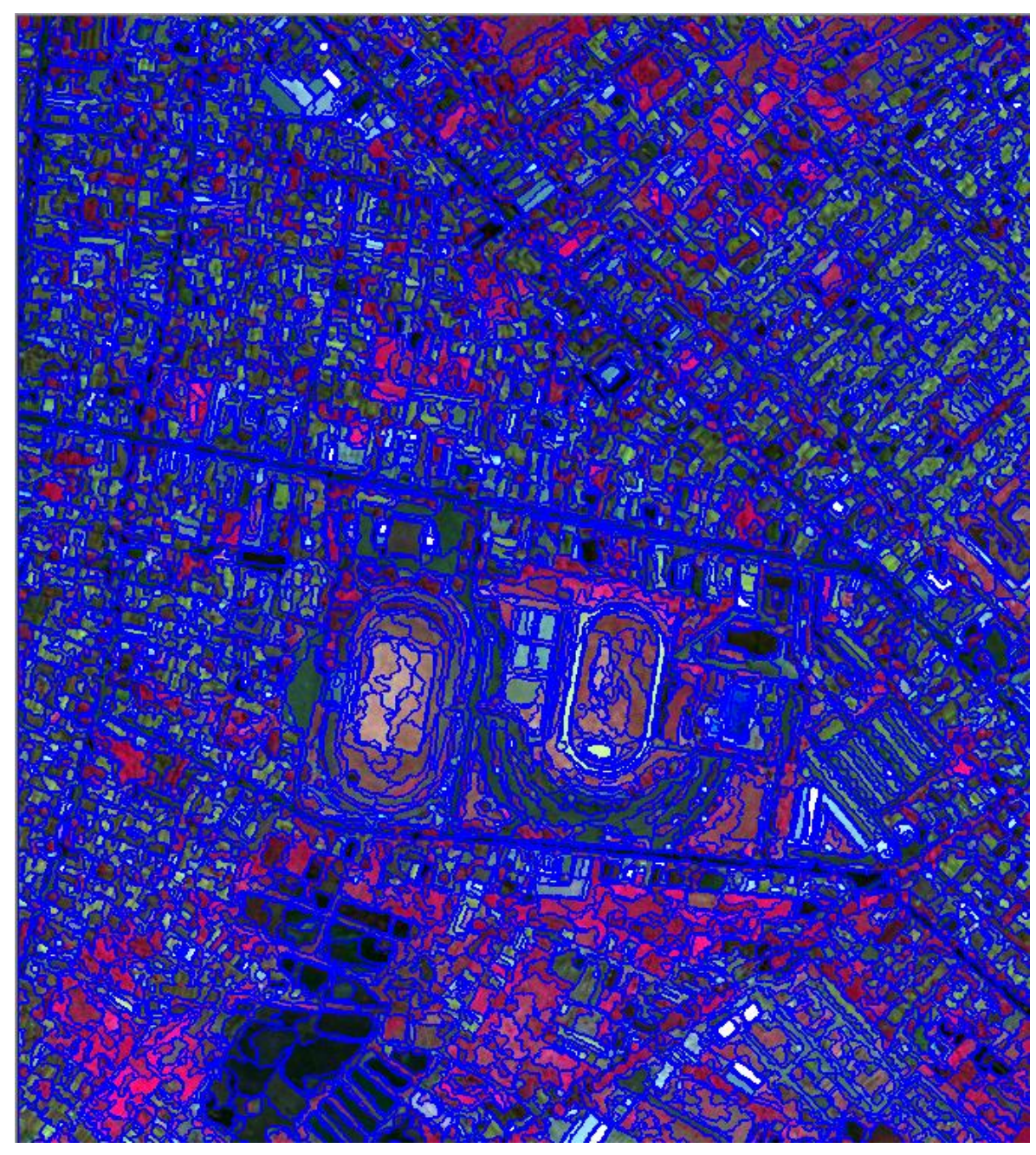

For groups of trees, separation of individual tree object was difficult to do. Single tree object that will be studied here whether consists of one or several grouped trees around non vegetation or around other vegetation but has significant spectral differences. Total generated objects were 4,518 objects for the entire area. 
Figure 6. Classification result of non-vegetation and vegetation (Analysis, 2015)

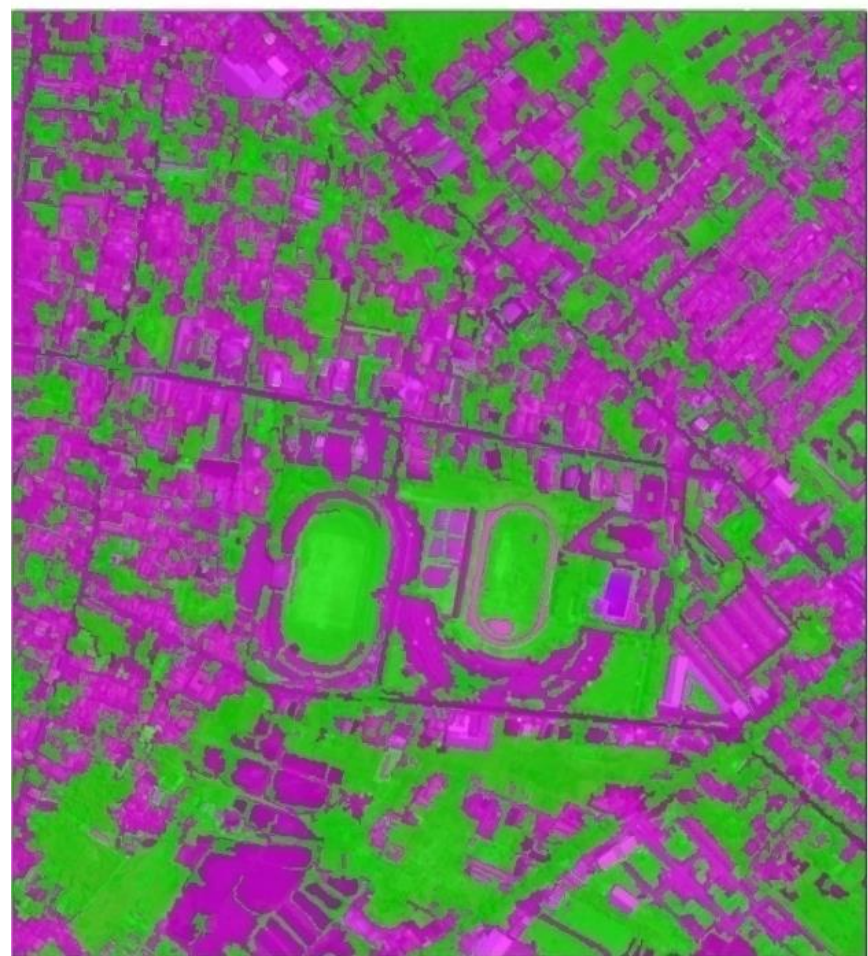

Non Vegetation

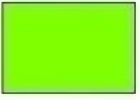

Vegetation

With the input feature consist of brightness, compactness, density, and mean spectral value of each band to classify the segmented image, vegetation and non-vegetation classes were obtained (Figure 6). The green area is vegetation class and the magenta area is non-vegetation class. From the results of the first classification, visually, the distribution of the classified area is consistent in accordance with the concept that the land cover vegetation will be red in the composite of Red-Green-NIR band and non-vegetation objects will be in another color, such as green, gray, blue, or white.

Figure 7. Imagery with vegetation only and second segmented image of the vegetation land cover (Analysis, 2015)

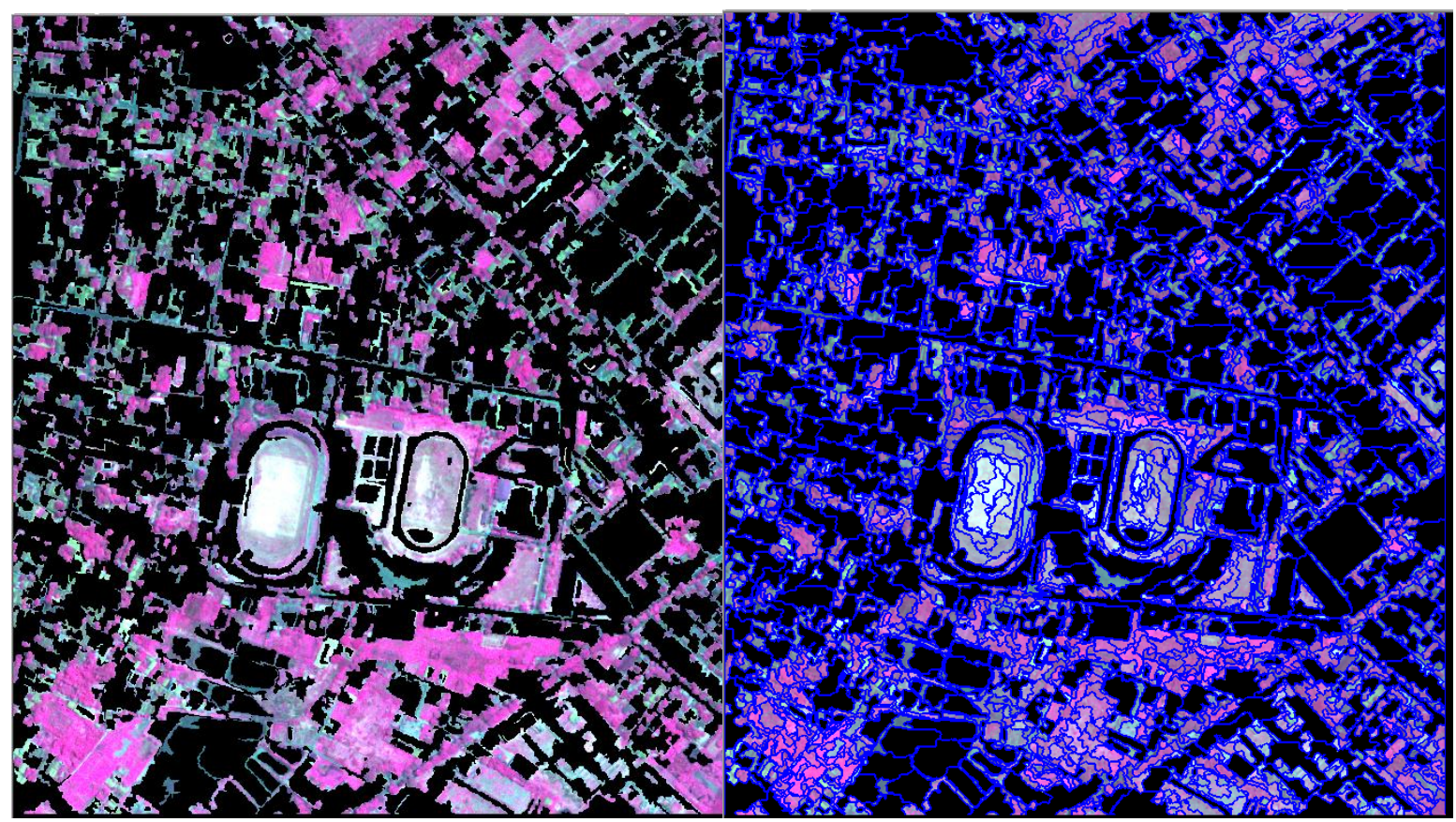


From the classification result, non-vegetation area was removed so only the vegetation area appears as the studied area (Figure 7). The next result is the second segmented image that conducted only on land cover vegetation. With the same scale of 30 , to obtain single tree object, 2,634 resulting objects were needed. It can be observed in the northern part of the study area that several single tree canopies were separated from the removed non vegetation forming tree spots. Single tree object is a target in the separation of object in this study. Some types of trees with a canopy were practically a type of vegetation that have a role in creating comfort in terms of thermal, keeping the wind and reduce levels of pollution in urban areas (Kadir \& Othman, 2012; Nasir et al., 2015).

Figure 8. NDVI value in vegetation land cover (Analysis, 2015)

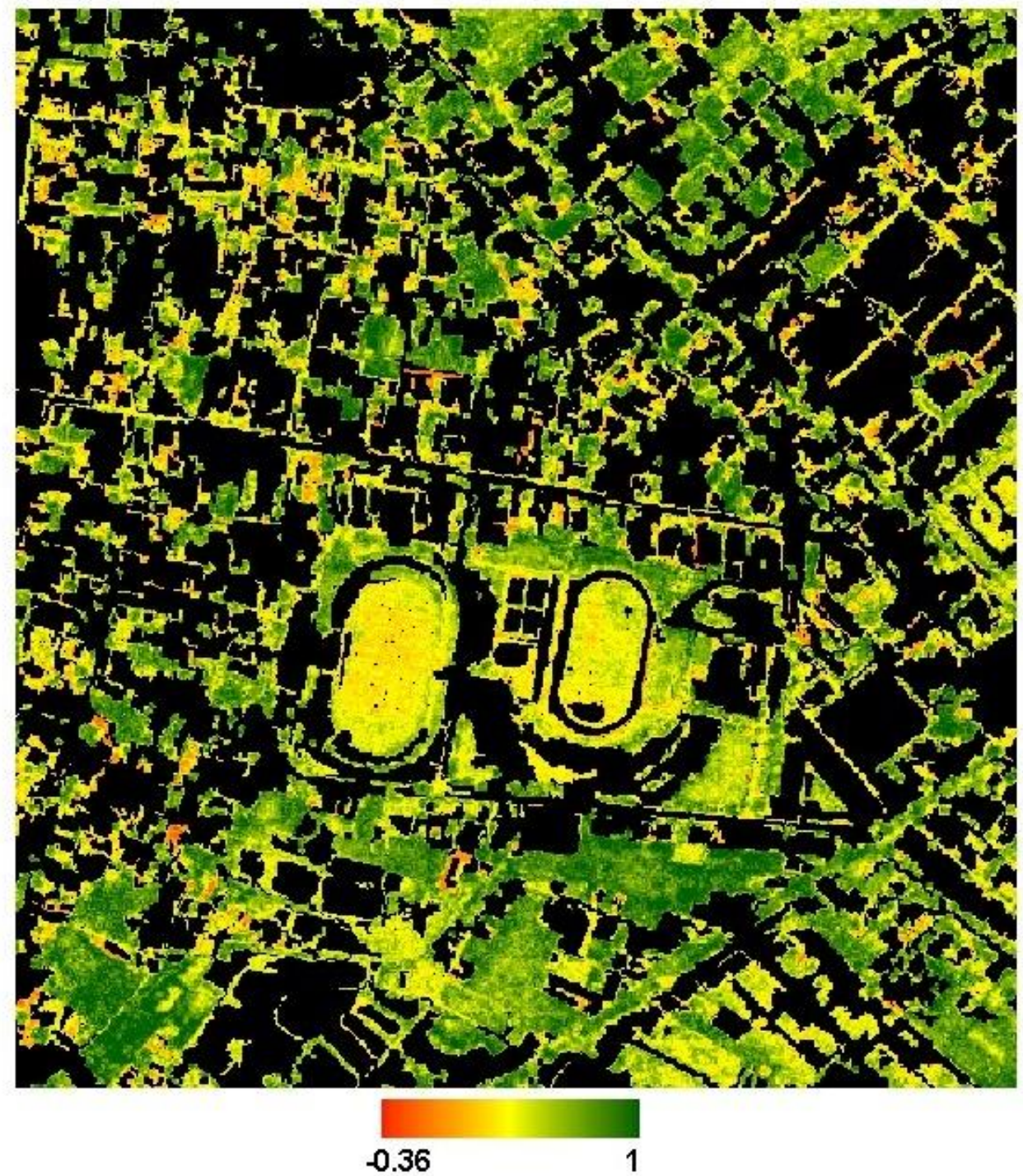

The transformation to NDVI value where the index indicates the green level of the existing vegetation in that area was subsequently acquired. In this analysis, land cover vegetation showed the overall vegetation. It is furthermore necessary to separate only tree objects for further analysis. Obtained index was ranged from -0.36 to 1 (see Figure 8), while negative value was shown in reddish and distribution was only shown as points that emerged as a result of error by non-vegetation area that included in, such as shadow, water or land in the segmentation using this scale. This emerging problem was due to the use of best scale in this work. The best scale for the separation of a single tree object is the most effective. If we use a smaller scale for a more detailed separation, the single object will be divided again since the sensitivity of the segmentation increases. 
Figure 9. Data training for classification 2 (Analysis, 2015)

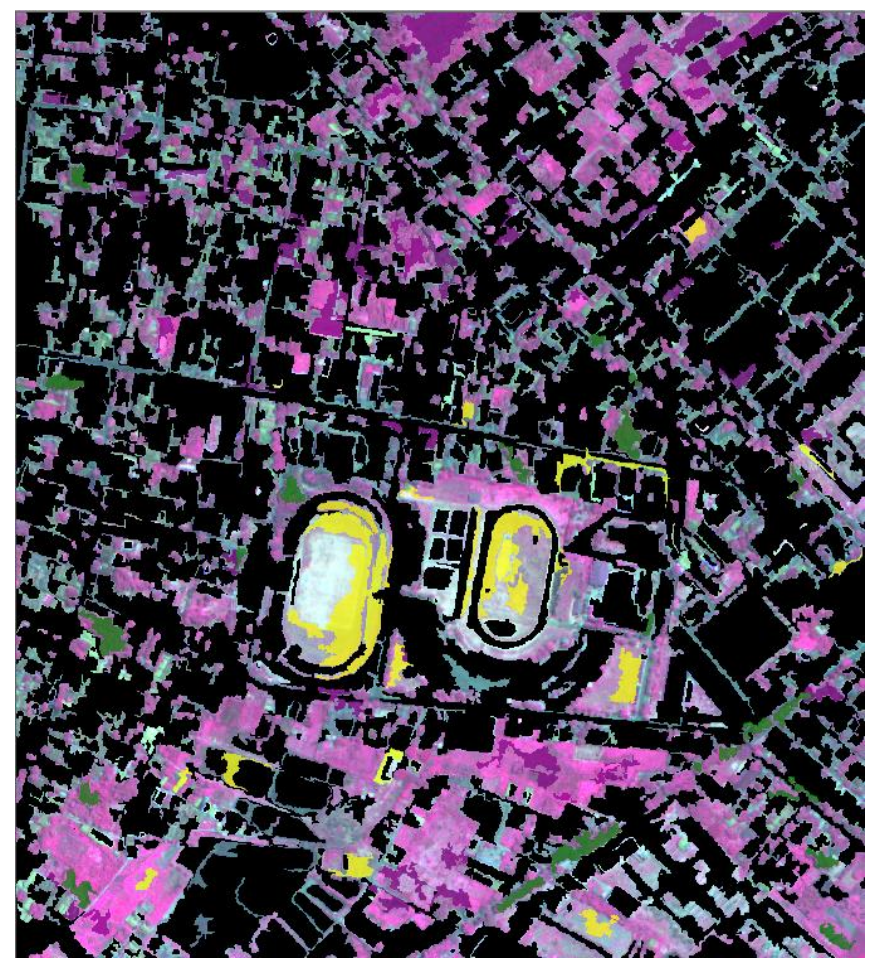

Land cover vegetation has been categorized into three classes, namely mixed garden, grass and tree. Selected training data on the study area were chosen with the reference of field surveys and visual interpretation. Selected training data (see Figure 9) represent the three classes with the difference visual appearance or spectral characteristics.

Figure 10. Land cover classification results: mixed cropping, grass and tree (Analysis, 2015)

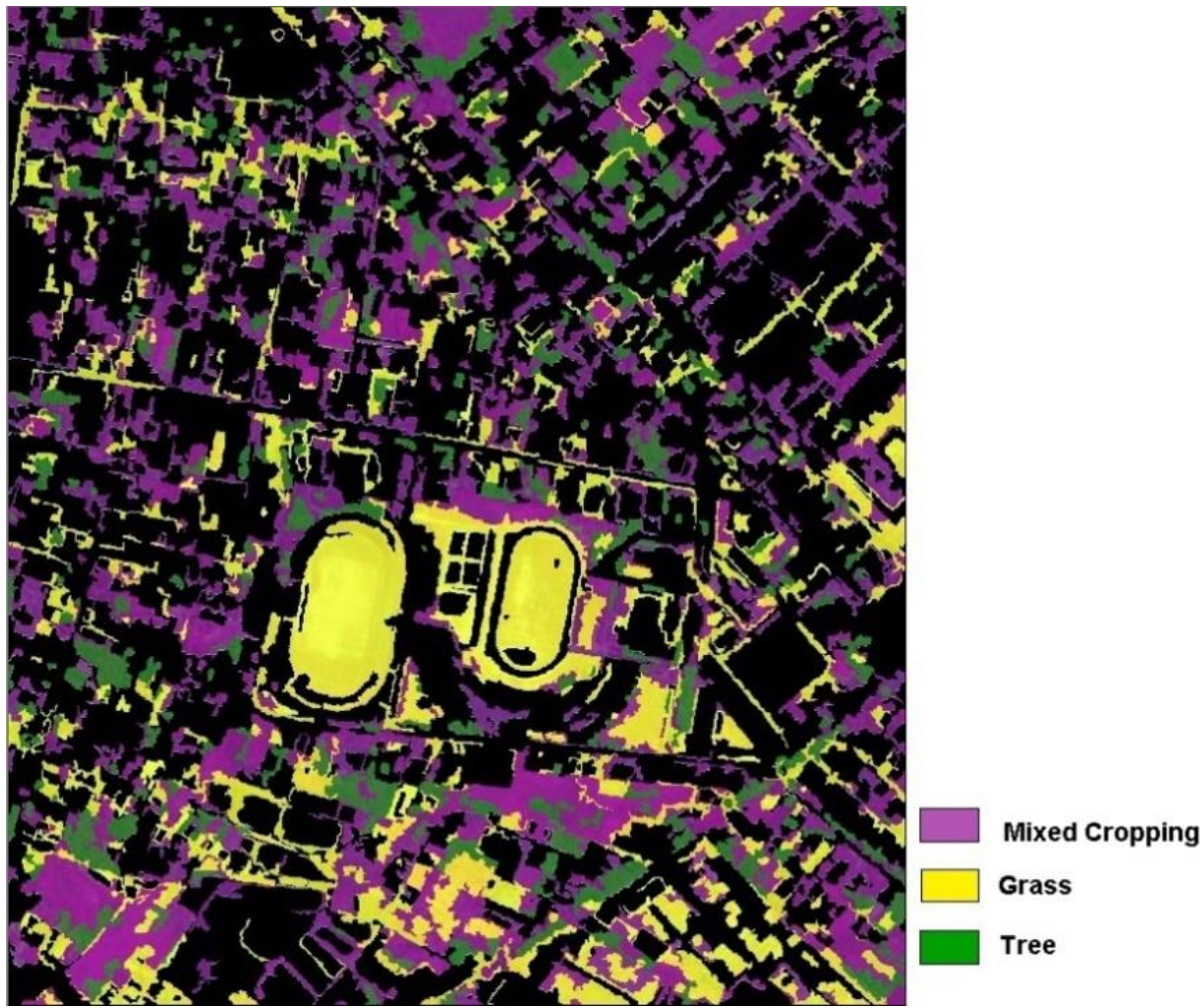


Figure 10 above is the result of three land cover classification. Three vegetation classes were made, namely grass, mixed cropping and trees. The result indicated that the class is dominated by mixed cropping in purple color distributed throughout the area.

Figure 11. Test data for test accuracy (Analysis, 2015)

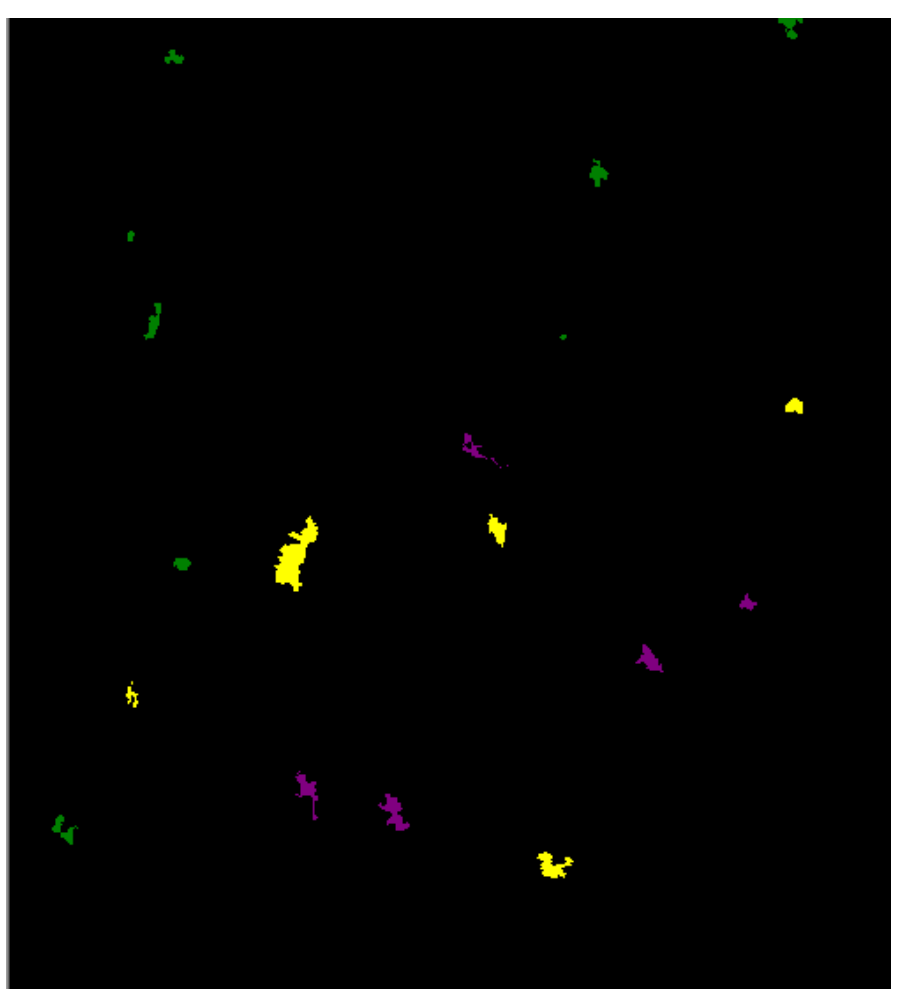

To assess the accuracy of the classification result in Figure 10, the selection of area as the test data was created based on the information on the result of field survey. Test data were selected by choosing different areas of the training data with visual characteristic representing each of the classes (mixed cropping, grass, and tree) (see Figure 11 and Table 1).

Table 1. Accuracy assessment result (Analysis, 2015)

\begin{tabular}{lrrr} 
User/Reference Class & Tree & Grass & Mixed Cropping \\
Tree & 88.476 & 0 & 0 \\
\hline Grass & 0 & 100 & 34.972 \\
\hline Mixed Cropping & 11.524 & 0 & 65.028 \\
\hline Unclassified & 0 & 0 & 0 \\
\hline Sum & & & 100 \\
\hline KIA Per Class & 100 & 1 & 100 \\
\hline Overall Accuracy & 0.847 & & 0.564 \\
\hline KIA & 0.878 & & \\
\hline
\end{tabular}

Accuracy assessment was calculated to observe the accuracy of the classification result for three classes. For tree classes, the accuracy was achieved at $88.48 \%$ while the remaining $11.52 \%$ was considered as class of mixed cropping. The number of tree pixels was 3,785 as opposed to 493 pixels in the area identified as mixed cropping. The second class achieved $100 \%$ of accuracy meaning that the whole area was identified as grass. The number of pixels was 7,166 . The last class, mixed cropping had the lowest accuracy $(65.03 \%)$ since the rest $34.97 \%$ was considered as grass. It is possible because some mixed garden area has visual similarities with grass. The total pixels identified as mixed cropping were 2,566 while the rest was grass with 1,380 pixels. Based on these results, total accuracy was obtained at $87.8 \%$ (Kappa coefficient $=$ 0.804). 
Figure 12. NDVI value for tree land cover (Analysis, 2015)

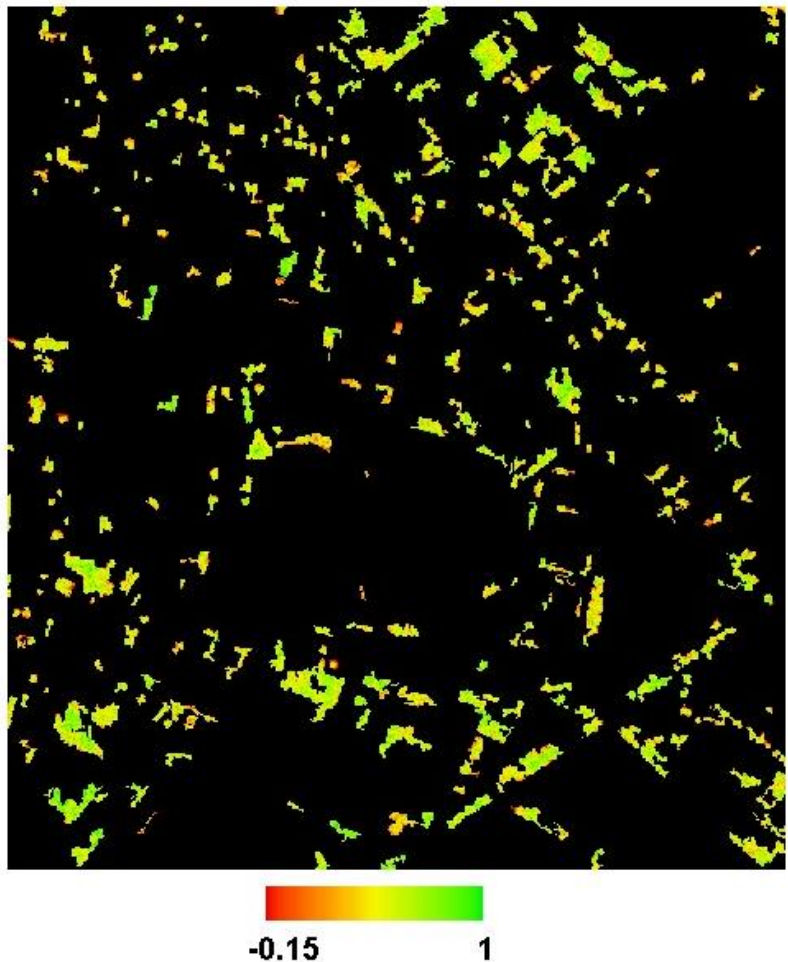

Analysis of the tree quality was done by calculating the NDVI value for tree class area, where the value ranged from -0.15 to 1 (see Figure 12). The negative value of NDVI in this area occurs due to certain area such as the shadow of vegetation was fused in tree polygon even though it is very small. The Figure $\mathbf{1 3}$ as field survey photo showed that there is a canopy of trees and shadows that could potentially create the mixel (mix pixel). It makes NDVI value calculated per pixel encountered an error for negative value occurrence in vegetation land cover. This error is inevitable since the non-vegetation part participates in the process of segmentation while the portions were precisely small and the scales used for segmentation was the most effective for object separation. The spatial distribution of NDVI value indicates that NDVI values close to 1 is dominant land cover of trees. Spatially, the trees in the northern part of residential areas have additional varied index value than trees in the southern part of the NDVI. In the southern part, the value is almost equal to 1 .

Figure 13. Field survey photos (Author, 2015)
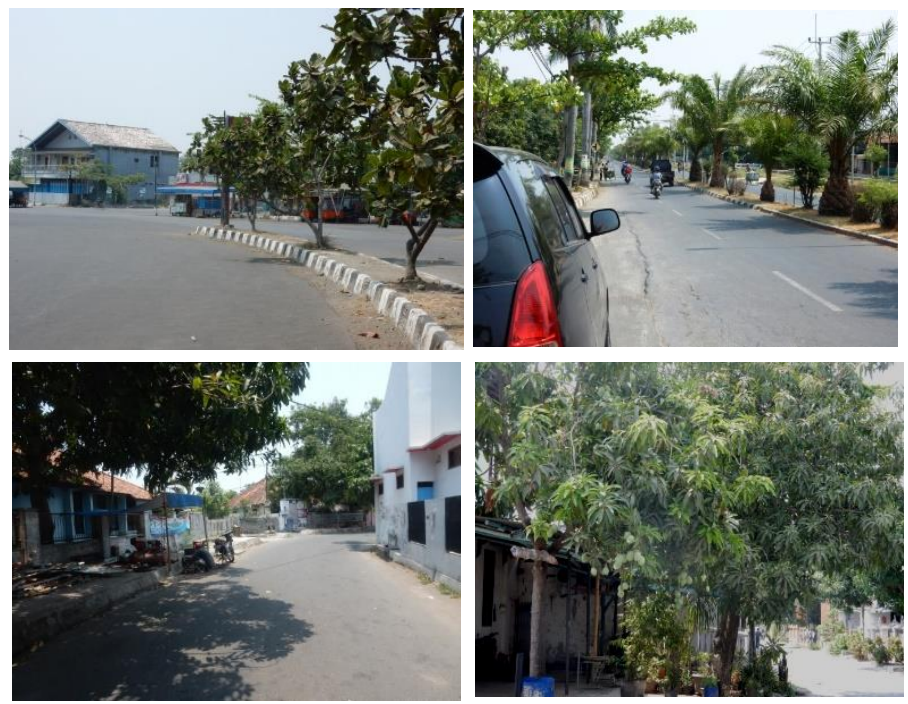
Figure 14. Tree land cover quality class (Analysis, 2015)

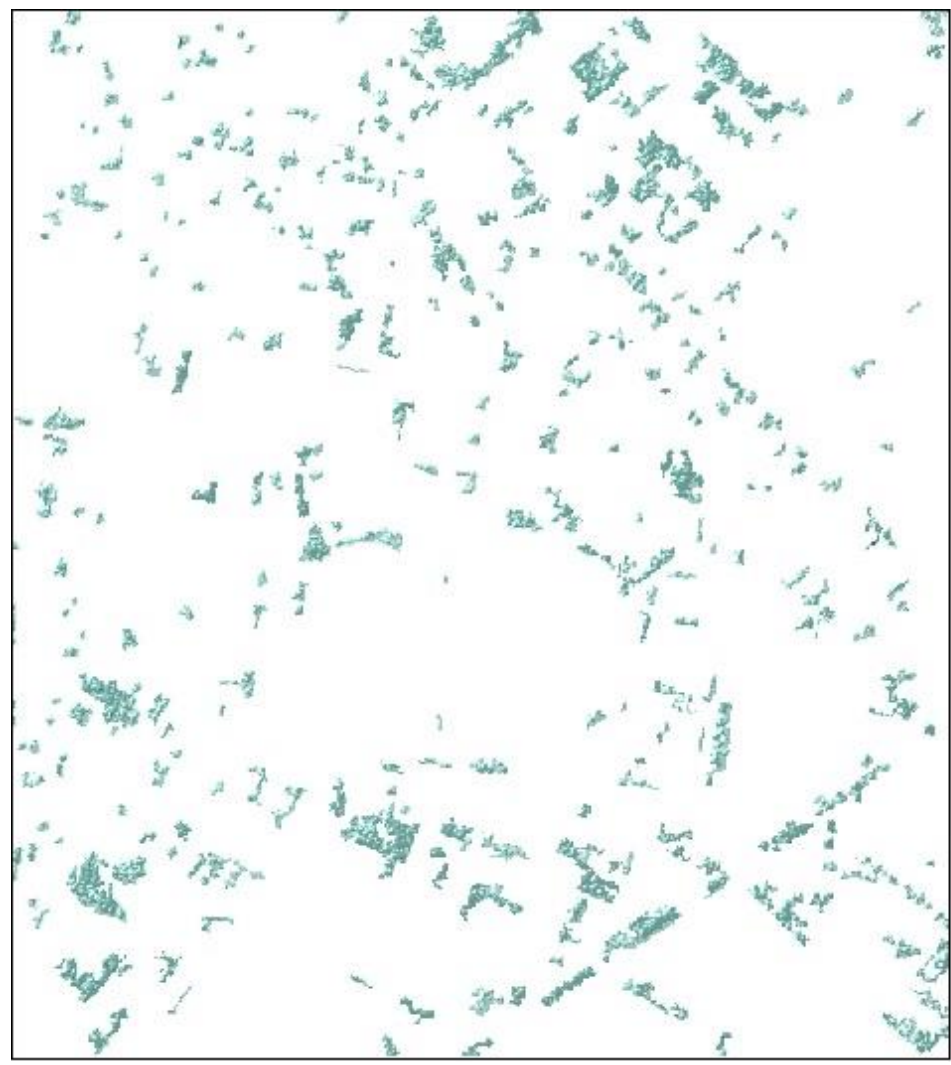

$$
\begin{aligned}
& \square \text { Very Low } \\
& \square \text { Low } \\
& \square \text { Maderate } \\
& \text { High } \\
& \text { Wery High }
\end{aligned}
$$

Appropriate vegetation index was calculated to observe the quality of vegetation, especially the tree. This class was created with the same interval of the indices, in which the very low class ranges from 0.15 to 0.06 ; the low class from 0.06 to 0.29 ; the moderate class from 0.29 to 0.53 ; the high class from 0.53 to 0.76 ; and the very high class ranges from 0.76 to 1 (see Figure 14). The gradation of color indicates the quality level of the trees where if the darker the colors get, the higher the quality of the tree. In the Northeast and South of the Stadium, tree canopy in the area is denser and darker in color showing the higher vegetation index.

Administratively, the area having a high-quality greenness of trees in the northern part is the settlement in the Northeast consisting of Jl. Rajawali, Jl. Belimbing, Jl. Rambutan, Jl. Anggur, Jl. Nanas and $\mathrm{Jl}$. Manggis. Variation of the quality of the trees in the northern part is observed where the northwestern part of the tree quality is lower, shown with a lighter color than in the Northeast. Settlement areas of this part are Jl. Kerukunan, Jl. Letjend. Suprapto, Jl. Jenderal Ahmad Yani, North part of Jl. Kapten Arya and around Jl. Olahraga. Further to the southern part of stadium area (southern part of Jl. Olahraga) tends to have a high greenness quality. Settlement in the area is around JI. Tanjung Pura and southern part of Jl. Kapten Arya.

\section{CONCLUSION}

This research has developed a method of multispectral remote sensing data utilization acquired by LAPAN LSA for the analysis of the single vegetation object with the OBIA classification method and vegetation index. The result of hierarchical classification accuracy with OBIA method for urban objects based on multispectral data was $88 \%$. Based on the analysis of vegetation quality with NDVI, the condition of trees in the urban area could be discovered.

\section{ACKNOWLEDGMENTS}

The authors deliver their gratitude to Aeronautic Technology Center LAPAN for the opportunity to use the LSA remote sensing data in this study. 


\section{REFERENCES}

Aburas, M. M., et al. (2015). Measuring land cover change in Seremban, Malaysia using NDVI index. Procedia Environmental Sciences, 30, 238-243. http://doi.org/10.1016/j.proenv.2015.10.043

Baatz, M., \& Schäpe, A. (2000). Multiresolution segmentation: an optimization approach for high quality multi-scale image segmentation. Angewandte Geographische Informationsverarbeitung XII, 58, 12-23.

Belgiu, M., \& Drăgut, L. (2014). Comparing supervised and unsupervised multiresolution segmentation approaches for extracting buildings from very high resolution imagery. ISPRS Journal of Photogrammetry and Remote Sensing, 96, 67-75.

Blaschke, T., et al. (2000). Object-oriented image processing in an integrated GIS/remote sensing environment and perspectives for environmental applications. Environmental Information for Planning, Politics and the Public, 2, 555-570.

Boukhabl, M., \& Alkam, D. (2012). Impact of vegetation on thermal conditions outside, Thermal modeling of urban microclimate, Case study: the street of the republic, Biskra. Energy Procedia, 18, 73-84.

Buyadi, S. N. A., Mohd, W. M. N. W., \& Misni, A. (2015). Vegetation's role on modifying microclimate of urban resident. Procedia-Social and Behavioral Sciences, 202, 400-407.

Chulafak, G. A., Annas, A., \& Kushardono, D. (2015). Pengolahan data kamera multispektral pada pesawat LSA-01 untuk pemantauan pertanian. In Prosiding Seminar Nasional Penginderaan Jauh 2015 (84-92).

$\mathrm{Du}, \mathrm{R}$. (2016). Urban growth: changes, management, and problems in large cities of Southeast China. Frontiers of Architectural Research, 5(3), 290-300. http://doi.org/10.1016/j.foar.2016.04.002

Gandhi, G. M., et al. (2015). NDVI: vegetation change detection using remote sensing and GIS--A case study of Vellore District. Procedia Computer Science, 57, 1199-1210.

Grundström, M., \& Pleijel, H. (2014). Limited effect of urban tree vegetation on $\mathrm{NO}_{2}$ and $\mathrm{O}_{3}$ concentrations near a traffic route. Environmental Pollution, 189, 73-76.

Janhäll, S. (2015). Review on urban vegetation and particle air pollution--Deposition and dispersion. Atmospheric Environment, 105, 130-137.

Jayawardhana, W., \& Chathurange, V. M. I. (2016). Extraction of agricultural phenological parameters of Sri Lanka using MODIS, NDVI time series data. Procedia Food Science, 6, 235-241.

Kadir, M. A. A., \& Othman, N. (2012). Towards a better tomorrow: street trees and their values in urban areas. Procedia-Social and Behavioral Sciences, 35, 267-274.

Kaimaris, D., Patias, P., \& Tsakiri, M. (2012). Best period for high spatial resolution satellite images for the detection of marks of buried structures. The Egyptian Journal of Remote Sensing and Space Science, 15(1), 9-18.

Karakiş, S., Marangoz, A. M., \& Büyüksalih, G. (2006). Analysis of segmentation parameters in ecognition software using high resolution quickbird ms imagery. In ISPRS Workshop on Topographic Mapping from Space.

Kerr, J. T., \& Dobrowski, S. Z. (2013). Predicting the impacts of global change on species, communities and ecosystems: it takes time. Global Ecology and Biogeography, 22(3), 261-263. http://doi.org/10.1111/geb.12036

Kim, J. Y., et al. (2015). Trends in a satellite-derived vegetation index and environmental variables in a restored brackish lagoon. Global Ecology and Conservation, 4, 614-624.

Kumar, D. (2015). Remote sensing based vegetation indices analysis to improve water resources management in urban environment. Aquatic Procedia, 4, 1374-1380.

Kushardono, D. (2014). Teknologi Akuisisi data pesawat tanpa awak dan pemanfaatannya untuk mendukung produksi informasi penginderaan jauh. Inderaja, v(7), 24-31.

Kushardono, D., et al. (2014). Pemanfaatan Data LSA (LAPAN Surveillance Aircraft) untuk Mendukung Pemetaan Skala Rinci. In Prosiding Pertemuan IImiah Tahunan XX MAPIN 2014.

Mondal, S., et al. (2014). Extracting seasonal cropping patterns using multi-temporal vegetation indices from IRS LISS-III data in Muzaffarpur District of Bihar, India. The Egyptian Journal of Remote Sensing and Space Science, 17(2), 123-134.

Nasir, R. A., et al. (2015). Adapting human comfort in an urban area: The role of tree shades towards urban regeneration. Procedia-Social and Behavioral Sciences, 170, 369-380. 
Pedersen, G. B. M. (2016). Semi-automatic classification of glaciovolcanic landforms: An object-based mapping approach based on geomorphometry. Journal of Volcanology and Geothermal Research, 311, 29-40.

Rajendran, S., Al-Sayigh, A. R., \& Al-Awadhi, T. (2016). Vegetation analysis study in and around Sultan Qaboos University, Oman, using Geoeye-1 satellite data. The Egyptian Journal of Remote Sensing and Space Science, in press.

Said, A. E., Shandoul, H. M. O., \& Yekhlef, Y. Z. (2013). Updating large scale maps using high resolution satellite image. APCBEE Procedia, 5, 435-440.

Sari, N. M., \& Kushardono, D. (2014). Klasifikasi penutup lahan berbasis obyek pada data foto UAV untuk mendukung penyediaan informasi penginderaan jauh skala rinci. Jurnal Penginderaan Jauh dan Pengolahan Data Citra Digital, 11(2), 114-127.

Sari, N. M., \& Kushardono, D. (2015). Pemanfaatan data foto LAPAN surveillance aircraft dengan kamera multispektral untuk melihat kualitas vegetasi pada ruang terbuka hijau perkotaan. In Prosiding Seminar Nasional Penginderaan Jauh 2015.

Saripin, I. (2003). Identifikasi penggunaan lahan dengan menggunakan Citra Landsat Thematic Mapper. Buletin Teknik Pertanian, 8(2), 54.

Takács, Á., et al. (2016). Microclimate modification by urban shade trees--An integrated approach to aid ecosystem service based decision-making. Procedia Environmental Sciences, 32, 97-109.

Tucker, C. J. (1979). Red and photographic infrared linear combinations for monitoring vegetation. Remote Sensing of Environment, 8(2), 127-150.

Wang, X., Wang, K., \& Zhou, B. (2011). Object-based classification of IKONOS data for endemic Torreya mapping. Procedia Environmental Sciences, 10, 1887-1891.

Zain, A. F. M., et al. (2015). The detection of urban open space at Jakarta, Bogor, Depok, and Tangerang-Indonesia by using remote sensing technique for urban ecology analysis. Procedia Environmental Sciences, 24, 87-94.

Zhang, X. X., Wu, P. F., \& Chen, B. (2010). Relationship between vegetation greenness and urban heat island effect in Beijing City of China. Procedia Environmental Sciences, 2, 1438-1450.

Zylshal, et al. (2016). A support vector machine object based image analysis approach on urban green space extraction using Pleiades-1A imagery. Modeling Earth Systems and Environment, 2(2), 54. http://doi.org/10.1007/s40808-016-0108-8 